\title{
Phenology in Calanus finmarchicus; hypotheses about control mechanisms
}

\author{
Charles B. Miller ${ }^{1}$, Timothy J. Cowles ${ }^{1}$, Peter H. Wiebe ${ }^{2}$, Nancy J. Copley ${ }^{2}$, \\ Helen Grigg ${ }^{3}$ \\ ${ }^{1}$ College of Oceanography, Oregon State University, Corvallis, Oregon 97331-5503, USA \\ ${ }^{2}$ Woods Hole Oceanographic Institution, Woods Hole, Massachusetts 02543, USA \\ ${ }^{3} 10$ Alexandra Road, Mutley Plain, Plymouth PL4 7JR, England
}

\begin{abstract}
Calanus finmarchicus (Gunnerus) stratify narrowly near $500 \mathrm{~m}$ depth during their fifth copepodite resting phase in North Atlantic Slope Water off southern New England, USA. They probably achieve this by migration to a specific, daytime isolume. Photoperiod information provided by light intensity at depth could serve as a cue for termination of the resting phase. Population data on tooth formation and gonad growth show that the resting stock prepares for termination in late winter and matures in February-March. Photoperiods are lengthening throughout that seasonal interval, and might cue arousal. An endogenous, 'long-range' timer that cues arousal after an interval of rest is another possible mechanism.
\end{abstract}

\section{INTRODUCTION}

Phenological features, particularly resting stages, do not receive sufficient attention in marine pelagic ecology, which tends to be distracted by trophic dynamics. Phenology is much more amenable to rapid evolution than are the acceptable temperature and nutritional ranges of a species. If temperature varies widely in a copepod's habitat, it is far easier for selection to adjust the time for taking refuge from conditions too warm or too cold (a matter of a few gene changes) than it is to adjust the whole metabolism and stay active, which requires gene changes in almost the entire metabolic machinery (Hochochka \& Somero 1984). Equally, a species can more rapidly adjust to a change in the timing of predatory activity by changing its rest timing, than it can by enhancing escape behavior, population dynamical parameters, or other strategies. Thus, it is to be expected that species will achieve local adaptation over broad geographic ranges primarily by adjusting their phenology. This is fully established for insects (Tauber et al. 1986). Some work has been done on such evolution to maintain appropriate temperature ranges in marine copepods that produce resting eggs (Marcus 1984, Uye 1986), and changes of timing to escape from predators have been fully established in limnetic cyclopoids (Nilssen 1980) and diaptomids (Hairston 1987. Hairston \& Olds 1987).
Another way of expressing the importance of resting stages is to say that they allow the animal to focus its 'reproductive potential' at the times of year when it will be most productive of surviving offspring. 'Reproductive value' (sensu Fisher 1930) often can be protected best by going to a dark hiding place for a portion of the life cycle. Many species do this (Tauber et al. 1986). Theoretical analysis (Caswell 1982) suggests that longterm payoffs are to be expected for such life history strategies. Models of copepod population processes would be much more satisfying if we had a clear understanding of the basic biology of resting phases. As shown below, resting phase mechanisms can be expected to be regionally and habitat specific. They are key enabling features in regional adaptive complexes, differing according to varying habitat demands.

\section{Phenology in calanoid copepods}

Life histories of mid- and high latitude, marine, calanoid copepods often include a resting phase. Acartia, Tortanus, and several other heterarthrandrid genera produce diapause eggs. In the Calanidae and related families (all among the amphascandrids) there is a quiescent phase, or possibly a true diapause (Elgmork \& Nilssen 1978), at one or more of the copepodite stages. There has been research on both types of rest- 
ing stage, and for resting eggs this has included some work on the events in the habitat that trigger diapause egg production (Johnson 1979, Marcus 1982, Sullivan \& McManus 1986) and on conditions allowing hatching of such eggs (Uye \& Fleminger 1976). Much less has been done with copepodite resting stages. Conover (1988) has reviewed work on the family Calanidae. Field studies show the seasonal timing of the resting phase and the range of the accompanying ontogenetic vertical migrations. However, there is little work on the mechanics of dormant phase onset or termination comparable to that for species with diapausing eggs.

A start on experimental work with Calanus finmarchicus was made by Grigg \& Bardwell (1982). We want to amplify the implications of their results here. There is some work on freshwater Cyclopoida, which also have copepodite resting stages. In particular, Watson \& Smallman (1971a, b) have shown that photoperiod, interacting with temperature, controls onset and termination of a diapause phase in several species of Diacyclops. We propose that in Calanus finmarchicus, as in Diacyclops, termination of the resting phase could occur in response to changing photoperiod. We argue that photoperiod information is available to the animals, despite the depth in the ocean at which the resting phase is spent. Other hypotheses are also open, particularly the possibility that an endogenous, longrange timer (Saunders 1982) cues arousal after an inter$\mathrm{val}$ of months regardless of external factors.

Knowledge of resting phases gives us strong insights about what matters to animals in their commerce with their habitat. As a means for escape from harsh circumstances, resting phases, often spent in refugia, are essential to survival. We must understand them to interpret ecological relationships and evolutionary history. Mechanisms of the resting phase probably differ among the Calanidae dominant in different regions (reviewed in the 'Discussion'). Thus, these are key adaptive variations for survival in habitats with different challenges.

\section{Phenology in Calanus}

The 'classical' phenological sequence in Calanus is that of Calanus finmarchicus as originally demonstrated in the Clyde Sea by Marshall et al. (1934) and in the Gulf of Maine by Bigelow (1926) and Fish (1936). Arctic data are provided by Tande (1982). In summer or early autumn individuals reaching the fifth copepodite stage (C5) load their oil sacs with lipids (known to be wax esters) and descend to depths greater than $200 \mathrm{~m}$ (Williams \& Conway 1988; present data), unless stopped by the bottom (Herman et al. in press) or an anoxic layer (Alldredge et al. 1984). Resting animals have empty guts with reduced epithelia (Hallberg \& Hirche 1980) and negligible or strongly reduced digestive enzyme activity (Tande \& Slagstad 1982, Hirche 1983, 1989). They move very little, exhibiting no hop-sink behavior. In some localities they have been reported unresponsive to poking (Hirche 1983), but we have observed that resting $\mathrm{C} 5$ 's in the Firth of Clyde and Gulf of Maine are always very responsive and will make strong escape jumps. Observations of feeding and substantial respiratory activity (Marshall \& Orr 1958, Butler et al. 1970, Corner et al. 1974) are all from specimens collected well above the usual depth zone for the resting phase, or the individuals used may have been disturbed from their rest during experimental measurements (see below). In winter, 1 to 3 mo after the solstice, the resting C5's molt, mature, and mate. The females move to surface layers, feed, and spawn. Development follows and C. finmarchicus completes 1 , 2 , or more generations before a late spring or summer generation re-enters dormancy. C. helgolandicus completes up to 5 generations from February to August (Williams 1985).

\section{Dormancy induction and termination in Calanus finmarchicus}

We can find no reports of experimental studies of the factors inducing the resting phase. For dormancy termination, the arousal phase, experiments by Grigg \& Bardwell (1982) suggest for Calanus finmarchicus and C. helgolandicus that there is a direct effect of light. They demonstrated that any time in the resting season C. finmarchicus are collected, sorted and held in dim, blue light they will begin the terminal molt after a $10 \mathrm{~d}$ lag (Fig. 1). In one tiny experiment some members of a group held in the dark did not molt for about $30 \mathrm{~d}$ (Tabie 1). These chance data suggest that light stimulates dormancy termination. It remains to protect the C5's from exposure to light before holding begins and to hold them under various illumination regimes.

Some similar experiments on maturation molts have been done by Hirche (1989). In June and August in the Fram Strait and Greenland Sea he sorted groups of C5 of Calanus finmarchicus from collections taken above $100 \mathrm{~m}$, a horizon in which digestive enzyme activity was higher than for C5 from 200 to $500 \mathrm{~m}$. The groups were held in the dark apart from checking for molts at regular intervals by sieving. There was typically a 20 to $30 \mathrm{~d}$ interval before substantial molting, which then proceeded rapidly. It is not clear that these specimens from above $100 \mathrm{~m}$ were resting, so it is uncertain whether the observed molts involved arousal from the rest phase.

In the field Calanus finmarchicus, C. helgolandicus, 
and C. pacificus (at various sites) all appear to mature over a rather brief interval centered on February. Since they remain at depth until they mature for mature very shortly after rising), it is not clear how they could receive a dose of light in mid-winter comparable to that in Grigg \& Bardwell's (1982) laboratory treatment. We now show some new data on the depth distribution of the resting phase off New England. Coupling these data to (1) morphological evidence on the timing of premolt development and (2) a consideration of light intensity cycling at mid-depth allows us to argue that arousal could be induced by lengthening photoperiod. Other mechanisms are also feasible, including an endogenous, long-range interval timer.

\section{METHODS}

Vertically stratified net collections were made in the upper 800 to $1000 \mathrm{~m}$ of the North Atlantic Slope Water during darkness at roughly monthly intervals from 29 April 1981 until 15 March 1982, with additional samples in May and June of 1982 (Table 2). Station locations were generally south of New England, USA, and were selected with the aid of satellite sea surface temperature images so as to avoid warm-core rings from the Gulf Stream. For all dates the $10^{\circ} \mathrm{C}$ isotherm was above $200 \mathrm{~m}$, an indicator of slope water proper. The sampler was the MOCNESS multiple net system (Wiebe et al. 1985). Hauls were subsampled by splitter, and abundances were estimated separately for females, males, fifth copepodites (C5's), and fourth copepodites (C4's)

Table 1 Calanus finmarchicus. Experimental results from Grigg \& Bardwell (1982). Numbers of adults and C5 individuals recovered from experimental containers after an incubation period at the habitat temperature. All but one batch (marked") were held in continuous light. Other details in Grigg \& Bardwell (1982)

\begin{tabular}{|c|c|c|c|c|c|c|}
\hline Date & $\begin{array}{l}\text { Duration } \\
\text { (d) }\end{array}$ & Food & $\begin{array}{l}\text { Initial } \\
\text { no. C5 }\end{array}$ & Males & Females & C5 \\
\hline \multirow[t]{2}{*}{14 Nov } & 26 & Absent & 55 & 12 & 41 & 2 \\
\hline & & Present & 72 & 17 & 54 & 1 \\
\hline \multirow[t]{2}{*}{$11 \mathrm{Dec}$} & 29 & Absent & 58 & 6 & 52 & 0 \\
\hline & & Present & 59 & 11 & 48 & 0 \\
\hline \multirow[t]{2}{*}{$11 \mathrm{Dec}$} & 29 & Absent & 20 & 7 & 13 & 0 \\
\hline & & Absent & 35 & 7 & 22 & $6^{\mathrm{d}}$ \\
\hline \multirow[t]{2}{*}{$16 \mathrm{Jan}$} & 23 & Absent & 58 & 13 & 44 & 1 \\
\hline & & Present & 60 & 17 & 42 & 1 \\
\hline \multicolumn{7}{|c|}{$\begin{array}{l}\text { a The reduced fraction maturing in this group held in darkness } \\
\text { is a key observation. It is not statistically significant. However, } \\
\text { it is reasonable to suppose that fully eliminating illumination } \\
\text { would increase the fraction not molting }\end{array}$} \\
\hline
\end{tabular}

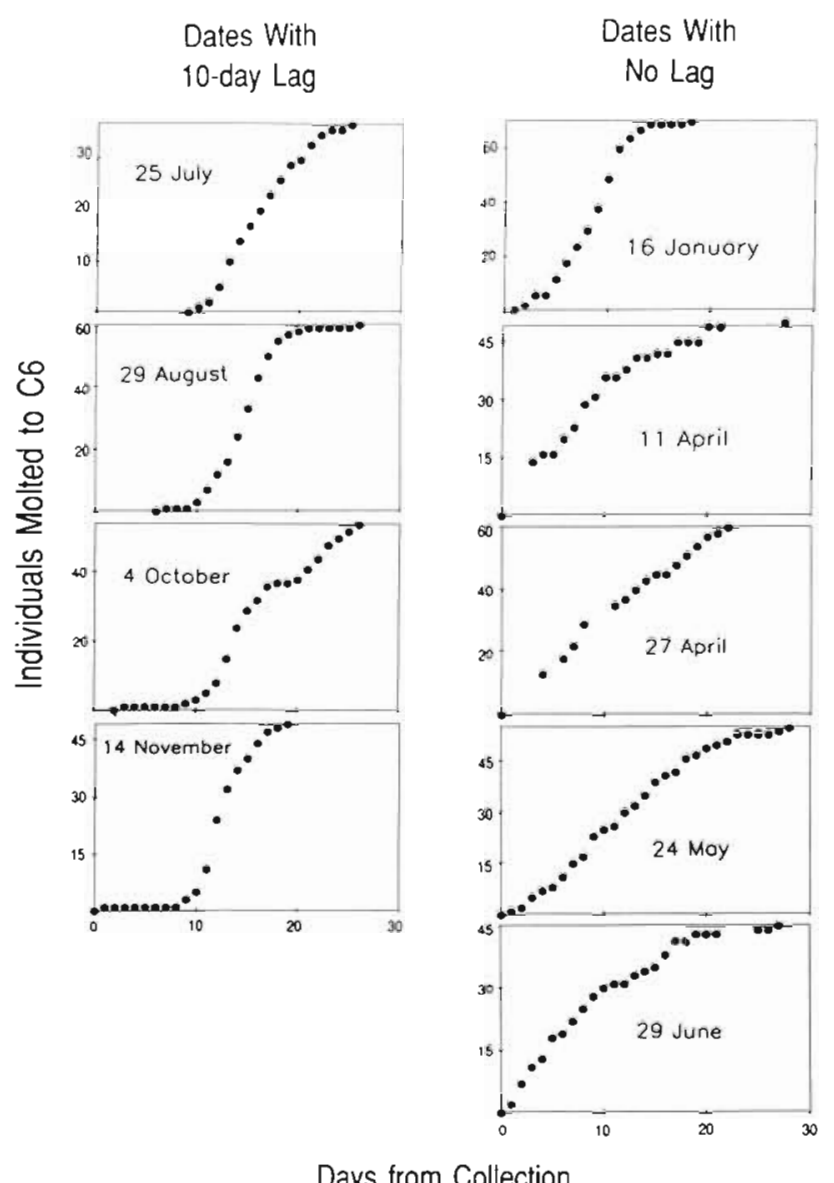

Days from Collection

Fig. 1 Calanus finmarchicus. Cumulative fraction of individual $\mathrm{C} 5$ molted to $\mathrm{C} 6$ at progressively later times following collection and distribution into containers held at constant, low illumination. Note particularly the $10 \mathrm{~d}$ lag to first molting from 25 July through 14 November. Redrawn from Grigg \& Bardwell (1982) by combining males and females, fed and unfed groups for each date. See the original for experimental details

of Calanus finmarchicus. Since the resting phase occurs during C5, this is sufficient detail for determination of its timing and vertical location.

Fifty to 60 specimens of C5 were sorted for morphological examination from the single sample at the abundance peak for each sampling date. Since during the resting phase at depth the C5's were mostly captured in a single MOCNESS sampling horizon, these samples represent the status of the stock. For spring months when C5 were abundant both at the resting depth and near the surface, specimens were examined from both peaks. We dissected and examined the mandibular gnathobases to determine the development phase of new teeth (Miller \& Nielsen 1988). Since teeth are the part of the copepod exoskeleton requiring most time to form, their state of development in the C5 gives an early indication of forthcoming ecdysis. Moreover, as reported by Miller \& Terazaki (1989) for Neocalanus 
Table 2. Station locations of MOCNESS hauls and depth intervals sampled in the North Atlantic Slope Water time series study. MOCNESS tows taken April through August were sampled in $100 \mathrm{~m}$ intervals from 8 to $800 \mathrm{~m}$ except for MOC-1-134 that sampled 800 to $600 \mathrm{~m}, 100 \mathrm{~m}$ intervals from 600 to $100 \mathrm{~m}, 100$ to $50 \mathrm{~m}$ and $50 \mathrm{~m}$ to the surface. The remaining 9-net tows, October through March, were sampled in $150 \mathrm{~m}$ intervals from 1000 to $400 \mathrm{~m}$ and in $100 \mathrm{~m}$ intervals from $400 \mathrm{~m}$ to the surface. One net in each 9 -net tow was open while shooting the net. The three 20 -net tows fished from 1000 to $200 \mathrm{~m}$ in $100 \mathrm{~m}$ intervals and from $200 \mathrm{~m}$ to $0 \mathrm{~m}$ in $25 \mathrm{~m}$ intervals. Two nets were used to balance the system during the tow, one while shooting and the other while hauling

\begin{tabular}{|c|c|c|c|c|}
\hline Date & Tow no. & Lat. & Long. & $\begin{array}{c}\text { No. of } \\
\text { nets }\end{array}$ \\
\hline 29 Apr 1981 & MOC-1-133 & $39^{\circ} 48^{\prime} \mathrm{N}$ & $69^{\circ} 57^{\prime} \mathrm{W}$ & 9 \\
\hline 13 May & MOC-1-134 & $39^{\circ} 47^{\prime} \mathrm{N}$ & $69^{\circ} 58^{\prime} \mathrm{W}$ & 9 \\
\hline 29 May & MOC-1-135 & $39^{\circ} 37^{\prime} \mathrm{N}$ & $71^{\circ} 00^{\prime} \mathrm{W}$ & 9 \\
\hline 29 Jun & MOC-1-136 & $39^{\circ} 40^{\prime} \mathrm{N}$ & $70^{\circ} 58^{\prime} \mathrm{W}$ & 9 \\
\hline $28 \mathrm{Jul}$ & MOC-1-137 & $39^{\circ} 45^{\prime} \mathrm{N}$ & $71^{\circ} 00^{\prime} \mathrm{W}$ & 9 \\
\hline 19 Aug & MOC-1-138 & $39^{\circ} 45^{\prime} \mathrm{N}$ & $71^{\circ} 00^{\prime} \mathrm{W}$ & 9 \\
\hline $3 \mathrm{Oct}$ & MOC-1D-145 & $40^{\circ} 15^{\prime} \mathrm{N}$ & $65^{\circ} 57^{\prime} \mathrm{W}$ & 20 \\
\hline $27 \mathrm{Oct}$ & MOC-1-148 & $39^{\circ} 39^{\prime} \mathrm{N}$ & $71^{\circ} 00^{\prime} \mathrm{W}$ & 9 \\
\hline 23 Nov & MOC-1-149 & $39^{\circ} 34^{\prime} \mathrm{N}$ & $71^{\circ} 02^{\prime} \mathrm{W}$ & 9 \\
\hline $13 \mathrm{Dec}$ & MOC-1-151 & $39^{\circ} 11^{\prime} \mathrm{N}$ & $70^{\circ} 02^{\prime} \mathrm{W}$ & 9 \\
\hline $5 \operatorname{Jan} 1982$ & MOC-1-152 & $39^{\circ} 41^{\prime} N$ & $71^{\circ} 07^{\prime} \mathrm{W}$ & 9 \\
\hline 8 Feb & MOC-1-153 & $39^{\circ} 38^{\prime} \mathrm{N}$ & $69^{\circ} 40^{\prime} \mathrm{W}$ & 9 \\
\hline $15 \mathrm{Mar}$ & MOC-1-158 & $39^{\circ} 57^{\prime} \mathrm{N}$ & $68^{\circ} 34^{\prime} \mathrm{W}$ & 9 \\
\hline $2 \mathrm{May}$ & MOC-1D-175 & $39^{\circ} 28^{\prime} \mathrm{N}$ & $70^{\circ} 57^{\prime} \mathrm{W}$ & 20 \\
\hline 16 Jun & MOC-1D-177 & $39^{\circ} 56^{\prime} \mathrm{N}$ & $71^{\circ} 32^{\prime} \mathrm{W}$ & 20 \\
\hline
\end{tabular}

spp., the resting phase retains the so-called 'postmolt' facies until termination of diapause. This is, then, an independent indication of the resting state in individuals living at great depth.

We classified the jaws of individuals according to the tooth development phases defined in Table 3. Postmolt and 'Late Postmolt' phases are not sharply distinct and could perhaps have been combined. However, there are distinctions among samples in the proportions of these phases, so we have retained them. The samples of 50 to 60 are small, which was necessary to make the large number of inter-sample comparisons possible. Sample size was adequate to show statistically significant and reasonably interpreted differences between dates.

We measured and determined the sex of developing gonads when they were visible without staining. The smallest anlagen require staining to be seen and measured, as was done by Tande \& Hopkins (1981). For the 8 February and 15 March samples, in which the gonads were large and obviously maturing, we made prosome length measurements, gonad measurements, and gonad sex evaluations in samples of 300 individuals. Prosome length was measured to check the observation by Grigg et al. (1985) that male C5 are on average
Table 3. Calanus finmarchicus. Definitions of molt cycle phases based on status of the hemocoele and of tooth development in the mandibular gnathobase. These vary slightly from Table 1 in Miller \& Nielsen (1988), which includes micrographs of gnathobases in these stages

Postmolt: The hemocoele extends into the expanded distal part of the gnathobase. It is seen as a large empty space between the epidermal tissue and the anterior exoskeleton

Late Postmolt: The hemocoele is still visible in the gnathobase, but it only extends into the isthmus portion

Intermolt: No sign either of hemocoele or of differentiation in the cytoplasm at the distal ends of the epidermal cells within the gnathobase. No apolysis space evident

Premolt: Showing any of several phases of new tooth development. This includes apolysis, presence of tooth molds in the ends of the epidermal cells, and full development of teeth ready for ecdysis
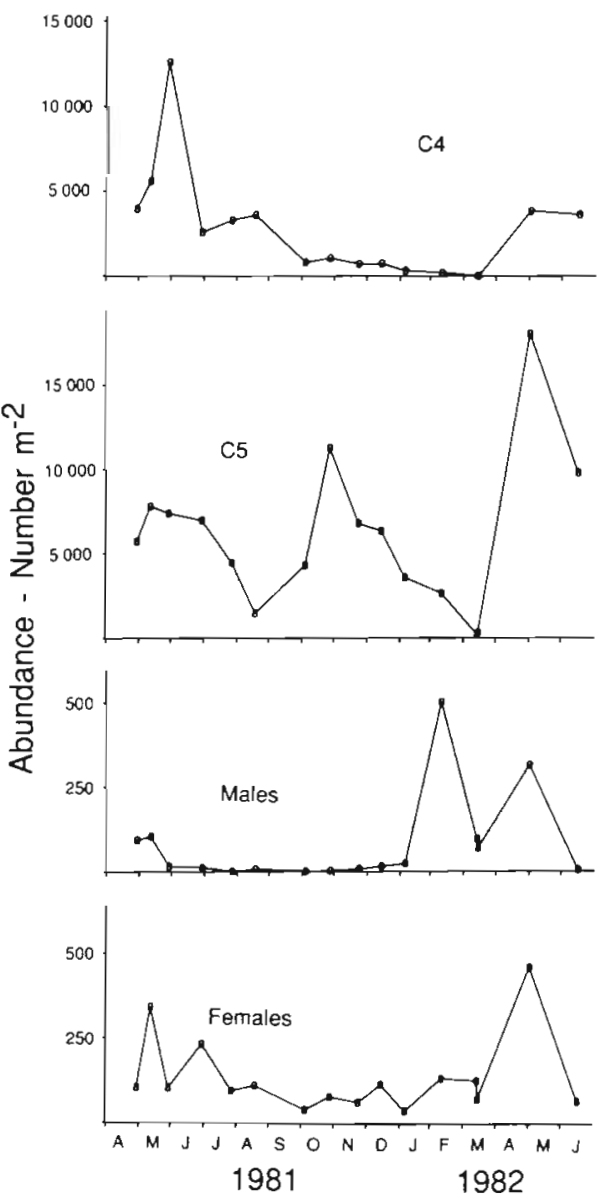

Fig. 2. Calanus finmarchicus. Integrated 10 to $800 \mathrm{~m}$, or 0 to $1000 \mathrm{~m}$ ) abundance estimates for several life stages derived from MOCNESS samples collected over the continental slope southeast of Cape Cod (Massachusetts, USA) 
larger than female $\mathrm{C} 5$. Testes are distinguished by fine granular texture, and a single duct emerging at the anterior end of the gonad then bending left and posteriorly (see Tande \& Hopkins 1981 for figures). Ovaries close to maturation have paired anterior diverticulae and (usually) oviducts visible along the sides of the thorax. Ovaries at an earlier stage have a coarsely granular texture. Many gonads, even those over $0.5 \mathrm{~mm}$ long, were not yet distinguishable as to sex.

\section{RESULTS}

\section{Abundance and depth distribution}

Abundance of the life cycle stages of Calanus finmarchicus oscillated seasonally during the study (Fig. 2). Fourth copepodites were most abundant in May-June, and present in smaller numbers through August. Fifth copepodites were usually present in excess of $4000 \mathrm{~m}^{-2}$. There was an unexplained dip during August. From autumn through March there was steady decline in the stock, which mostly was at depth in the resting phase (see below). The decline must have been due to a combination of dispersal into offshore waters, mortality, and molting to C6. The final decline in February and March can be attributed to molting to the C6, since the stocks of first males (8 February) and then females (late April-May of both years) peaked then. The 15 March 1982 sample was taken close to Gulf Stream warm-core ring $82-\mathrm{B}$, so that abundance may have been lower than for Slope Water generally.

Abundance of adults was low from summer through mid-winter (Fig. 2). The C5 had an essentially inverse pattern, being the dominant stage in summer and autumn. In Slope Waters, as elsewhere, the C5 clearly is a resting phase. They molt to $\mathrm{C} 6$ in February-March, and the resulting adults reproduce. Development of their offspring occurs in late winter to spring with return to C5 by May-June.

From May through February the C5 stayed remarkably close to $500 \mathrm{~m}$ (Fig. 3). Typically there was a very strong mode, well over half the population, in the single sample that included $500 \mathrm{~m}$. Several vertical profiles (Fig. 4) illustrate the narrow stratification of the population, especially during the later parts of the rest phase. Given the 100 to $150 \mathrm{~m}$ thickness of the sampling strata, the centering of the population may well have been even more pronounced than our data can show. During the period when most individuals are resting as $\mathrm{C} 5$, there were always some younger copepodites and some females present. These also centered between 400 and $600 \mathrm{~m}$ (Fig. 3). Occupation of near-surface layers was restricted to March through May for all stages. Accurate distribution patterns were difficult to determine for males because of their low abundance. However, when they were numerous in February and March 1982, they too clustered around $500 \mathrm{~m}$. In April 1982, the center of the male population was shallower.

\section{Development}

Fifth copepodites from shallow, spring samples had greater proportions of 'Late' Postmolt and Intermolt

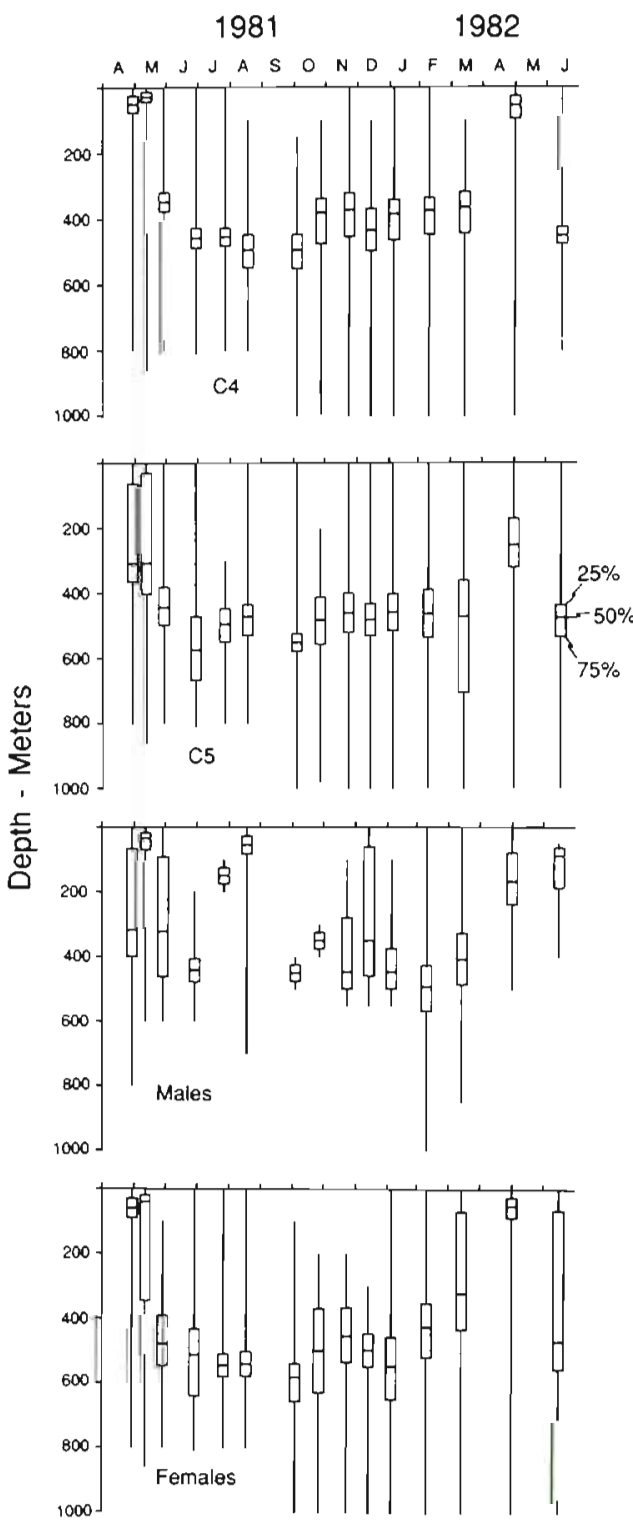

Fig. 3. Calanus finmarchicus. Vertical distributions of life stages. For each date in 1981-1982 the vertical lines represent the range of all captures. The boxes extend from the depth below which $25 \%$ of the population was found to that above which $75 \%$ was found. The crossbar in the box is at the median population depth 
individuals than those from deep samples, except for November, February and March (Table 4). Since jaws of $\mathrm{C} 5$ from around $500 \mathrm{~m}$ in mid-summer so strongly

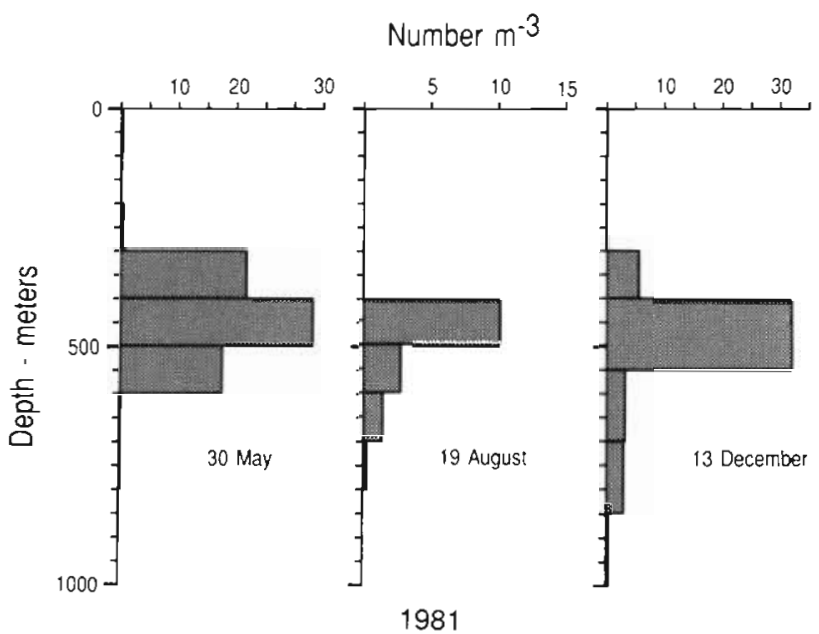

Fig. 4. Calanus finmarchicus. Three examples of data derived from MOCNESS samples showing the depth distribution of resting phase copepods. There is consistently a very strong mode in one sample retain the Postmolt facies, we suspect that the substantial fraction of near-surface C5's with Late Postmolt and Intermolt facies in late April or May were proceeding with development. There is no sign in the present data set that spawning by these adults produces another, complete generation.

Gnathobases of $\mathrm{C} 5$ from the deep samples of summer were nearly all in Postmolt or 'Late' Postmolt phase. This agrees with Miller \& Terazaki's (1989) observations for Neocalanus spp. Samples for late autumn and winter did not progress monotonically from lesser to greater fractions developing teeth. The 400 to $550 \mathrm{~m}$ samples for 23 November and 13 December show progress in proportions with late postmolt and intermolt facies, but that for 5 January has proportions like the mid-summer samples. The gonad data (see below) suggest that the November specimens were more advanced than either the December or January ones. There is surely local variability in such development, and we make no claim to be repeatedly sampling exactly the same population. We can only look for general trends. Both February and March samples showed by far the highest proportions of premolt indi-

Table 4. Calanus finmarchicus. Jaw development phase determinations for C5 from the Slope Water sample series

\begin{tabular}{|c|c|c|c|c|c|c|}
\hline \multirow[t]{2}{*}{ Date } & \multirow[t]{2}{*}{ Depth $(\mathrm{m})$} & \multicolumn{4}{|c|}{ No. of specimens with jaws in given phases: } & \multirow[b]{2}{*}{ Total } \\
\hline & & Postmolt & 'Late' Postmolt & Intermolt & Premolt & \\
\hline \multicolumn{7}{|c|}{ Shallow samples } \\
\hline 29 Apr 1981 & $0-100 \mathrm{~m}$ & 13 & 18 & 28 & 0 & 59 \\
\hline $12-13$ May & $0-50$ & 13 & 31 & 16 & 0 & 60 \\
\hline 29 May & $0-100$ & 1 & 1 & 1 & $1^{\mathrm{a}}$ & 4 \\
\hline 2 May 1982 & $0-75$ & 24 & 22 & 14 & $2^{\mathrm{b}}$ & 62 \\
\hline 29 Jun & $50-75$ & 9 & 0 & 1 & 0 & 10 \\
\hline \multicolumn{7}{|l|}{ Deep samples } \\
\hline 29 Apr 1981 & $400-500$ & 40 & 13 & 1 & $1^{\mathrm{b}}$ & 55 \\
\hline 12-13 May & $400-500$ & 41 & 13 & 1 & 0 & 55 \\
\hline 29 May & $400-500$ & 51 & 9 & 0 & 0 & 60 \\
\hline 29 Jun & $500-600$ & 53 & 0 & 0 & 0 & 53 \\
\hline 28 July & $400-500$ & 47 & 5 & 0 & 0 & 52 \\
\hline 19 Aug & $400-500$ & 46 & 8 & 1 & 0 & 55 \\
\hline 3 Oct & $500-600$ & 58 & 2 & 0 & 0 & 60 \\
\hline $27 \mathrm{Oct}$ & $400-550$ & 51 & 9 & 0 & 0 & 60 \\
\hline 23 Nov & $400-550$ & 40 & 19 & 0 & $2^{c}$ & 61 \\
\hline $13 \mathrm{Dec}$ & $400-550$ & 21 & 3 & 36 & 0 & 60 \\
\hline 5 Jan 1982 & $400-550$ & 53 & 6 & 1 & 0 & 60 \\
\hline $8 \mathrm{Feb}$ & $400-550$ & 16 & 17 & 9 & $13^{\mathrm{d}}$ & 55 \\
\hline $15 \mathrm{Mar}$ & $400-550$ & 31 & 3 & 10 & $11^{\mathrm{e}}$ & 55 \\
\hline 2 May & $400-500$ & 54 & 4 & 0 & 0 & 58 \\
\hline $29 \mathrm{Jun}$ & $400-500$ & 50 & 2 & 0 & 0 & 52 \\
\hline \multicolumn{7}{|c|}{$\begin{array}{l}\text { a } 0.43 \mathrm{~mm} \text { ovary } \\
\text { b No gonads visible } \\
{ }^{\mathrm{c}} \text { Both with gonad }>0.5 \mathrm{~mm} \text {; both identifiable as testes } \\
{ }^{\mathrm{o}} 10 \text { with gonad }>0.5 \mathrm{~mm}_{\mathrm{i}} 7 \text { identifiable as testis } \\
{ }^{\mathrm{e}} 8 \text { with gonad }>0.5 \mathrm{~mm} ; 6 \text { identifiable as testis, } 1 \text { as ovary }\end{array}$} \\
\hline
\end{tabular}


Table 5. Calanus finmarchicus. Gonad size in C5 from the Slope Water sample series. Gonads were first visible in the sample of 23 November. There were again none on 13 December January, February, and March samples had increasing proportions of large gonads and gonads identifiable as testis or ovary

\begin{tabular}{|c|c|c|c|c|c|c|}
\hline \multicolumn{7}{|c|}{ Smaller samples from all dates with significant number of visible gonads: } \\
\hline Date & No gonad & $<0.2 \mathrm{~mm}$ & $0.2-0.3$ & $0.3-0.4$ & $0.4-0.5$ & $>0.5 \mathrm{~mm}$ \\
\hline 27 Oct 1981 & 60 & 0 & 0 & 0 & 0 & 0 \\
\hline $23 \mathrm{Nov}$ & 4 & 9 & 15 & 15 & 15 & 3 \\
\hline $13 \mathrm{Dec}$ & 60 & 0 & 0 & 0 & 0 & 0 \\
\hline 5 Jan 1982 & 9 & 4 & 10 & 13 & 16 & 7 \\
\hline 8 Feb & 2 & 5 & 6 & 9 & 12 & 19 \\
\hline $15 \mathrm{Mar}$ & 4 & 7 & 6 & 13 & 7 & 14 \\
\hline \multicolumn{7}{|c|}{ Larger samples from 8 Feb and 15 Mar 1982: } \\
\hline Date & No gonad & $<0.2 \mathrm{~mm}$ & $0.2-0.3$ & $0.3-0.4$ & $0.4-0.5$ & $>0.5 \mathrm{~mm}$ \\
\hline 8 Feb 1982 & 11 & 30 & 28 & 49 & 58 & 117 \\
\hline Percent & 4 & 10 & 10 & 17 & 20 & 40 \\
\hline 15 Mar 1982 & 33 & 43 & 38 & 64 & 43 & 67 \\
\hline Percent & 12 & 15 & 13 & 22 & 15 & 23 \\
\hline \multicolumn{7}{|c|}{ Gonads $<0.3 \mathrm{~mm}$ were all undifferentiated. Some gonads in larger categories are distinguishable as testes or ovaries } \\
\hline Date & Status & $0.3-0.4$ & $0.4-0.5$ & $>0.5 \mathrm{~mm}$ & & \\
\hline \multirow[t]{3}{*}{8 Feb 1982} & Testis & 2 & 14 & 51 & & \\
\hline & Ovary & 8 & 21 & 44 & & \\
\hline & Undiff. & 39 & 23 & 22 & & \\
\hline \multirow[t]{3}{*}{15 Mar 1982} & Testis & 4 & 11 & 21 & & \\
\hline & Ovary & 8 & 14 & 38 & & \\
\hline & Undiff. & 52 & 25 & 8 & & \\
\hline
\end{tabular}

viduals". Thus the tooth development data are consistent with strong onset of arousal from the C5 resting phase in February. Observed tooth development does not, however, suggest that arousal is sharply simultaneous for stocks distributed in the Slope Water off southern New England.

None of the deep samples from spring through 27 October had any specimens with visible gonads (Table 5). Gonads first appeared in the 23 November sample, but none were seen in the 13 December sample. Gonads exceeding $0.5 \mathrm{~mm}$ were first seen in the 5 January sample and were found in an increasing proportion of individuals on 8 February and 15 March. More convincingly than jaw development, gonad

\footnotetext{
- All of the pairwise sample comparisons characterized as different here were found to be statistically significant at $p=$ 0.001 by Chi-square test for $H_{0}$ : both samples were from the same multinomial distribution. There are 306 pairwise comparisons for $n \geq 52$. Thus, only $306 \times p=0.3$ are expected to be significant at this level by chance. Moreover, all of the observed differences make good biological sense and agree with everything known about the resting phase and development of Calanus finmarchicus
}

growth and differentiation suggest that arousal from the resting phase and maturation begins in mid-winter (January) and occurs for much of the population in February-March.

Most of the gonads larger than $0.4 \mathrm{~mm}$ on both 8 February and 15 March could be distinguished as to sex (Table 5, lower part). For those over $0.5 \mathrm{~mm}$, there was a significant contingency of observed sex with the month: February had more males, March more females. This agrees with a general trend in the Calanidae for males to appear first in seasonally breeding species.

There was a strong tendency in February and March for testes to occur mostly in individuals from the upper portion of the size range. Individuals with ovaries were found all across the size range, but they were mostly of modal size and smaller (Fig. 5).

\section{DISCUSSION}

\section{Depth distribution}

Our data show the resting stock as consistently centered near $500 \mathrm{~m}$. There are few published accounts of the 

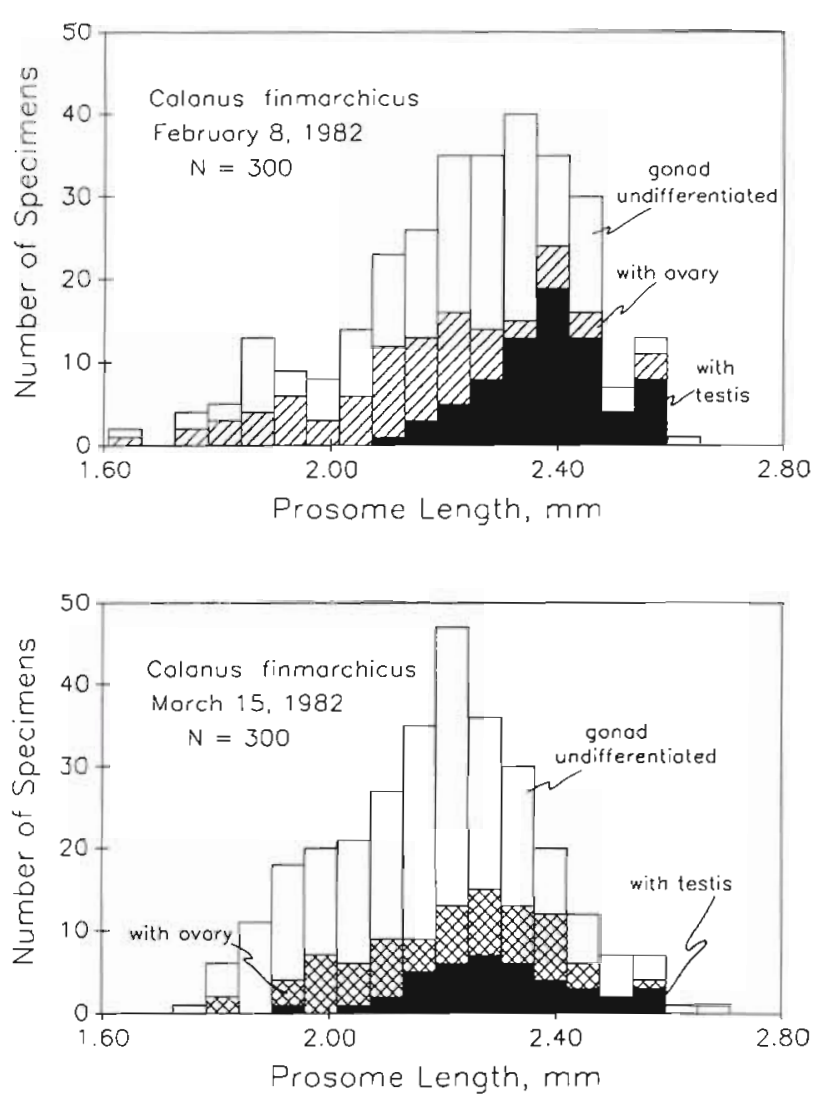

Fig. 5. Calanus finmarchicus. Histograms of body size of C5 sorted from the 400 to $500 \mathrm{~m}$ samples of 8 February and 15 March 1982. Individuals with gonads identifiable as testes are indicated in black; those with ovaries are indicated by diagonal hatching. Males are derived mostly from larger specimens; females are developed from the whole distribution but are more strongly represented among modal and smaller specimens

vertical distribution of Calanus finmarchicus in oceanic waters. Williams \& Conway (1988, Fig. 4) show a seasonal sequence of distributions from LHPR (Longhurst-Hardy plankton recorder) sampling that reached $1000 \mathrm{~m}$ at continental slope stations southwest of the British Isles. Profiles from the resting phase of the life cycle (January, July, September, and December) all showed maximum peaks of fifth copepodites at or near 500 to $600 \mathrm{~m}$. This resembles our result. However, in at least the September profile, a substantial fraction of the total population scattered downward from the $500 \mathrm{~m}$ mode to at least $1000 \mathrm{~m}$. Data covering 0 to $500 \mathrm{~m}$ from 4 yr of spring-summer sampling at Weather Station 'I' $\left(59^{\circ} \mathrm{N}, 19^{\circ} \mathrm{W}\right.$ ) (Williams 1988) showed late season accumulation of $C$. finmarchicus between 400 and $500 \mathrm{~m}$. The bulk of the stock could have been deeper. A pair of day-night LHPR profiles from ' $I$ ' in late March 1975 showed an abundant stock extending from $350 \mathrm{~m}$ down to the limits of sampling at $650 \mathrm{~m}$ (day) and $550 \mathrm{~m}$ (night). Williams's data overall suggest that farther to the east the resting stock may reside somewhat deeper than we observed over the New England continental slope.

\section{Generatíons per year}

Our sample series from Slope Water off southern New England shows only one successful generation during the year, that from eggs spawned by females that matured in the winter of $1980 / 81$. However, the tooth development data for near-surface samples (Table 4) suggest that at least a fraction of the population did not enter the resting phase but molted immediately to C6. Sherman (1980) found that Calanus finmarchicus are abundant considerably longer each year in the colder waters of the Gulf of Maine than in Slope Waters off southern New England. He found termination of high surface abundance off southern New England exactly when we did. However, persistence of high abundance through September in the Gulf of Maine suggests a complete second generation. Our development data suggest that both strategies are attempted off southern New England, but the second generation simply fails.

\section{Gonad development and sexual size dimorphism}

Our data on gonad size in C5 from near $500 \mathrm{~m}$ differ from those of Tande \& Hopkins (1981) for Calanus finmarchicus collected in Balsfjorden. Their population showed a majority of 'P1' and 'P2' individuals from June onward, categories for which the gonad was smaller than we could see (less than $0.2 \mathrm{~mm}$; we did not use their staining technique). However, the appearance of a large fraction of definite males among the C5 occurred both in their location and ours in January/ early February, and female C5 predominated after that.

It has been recognized previously for eastern Atlantic populations (Grigg et al. 1981, 1985, 1987, 1989) that males of Calanus finmarchicus mostly derive from the upper end of the size range of C5's, females from the lower. Our data (Fig. 5) demonstrate that this is also true for western Atlantic populations.

\section{The arousal mechanism}

Facts we have established constrain hypotheses about termination of the $\mathrm{C} 5$ resting phase of Calanus finmarchicus. Those facts are: (1) Arousal can be stimulated at any time during the resting phase with molting after a $10 \mathrm{~d}$ lag (Fig. 1). The most likely stimulus, based on the experiments available, is a change in the intensity or timing of illumination (Grigg \& Bardwell 1982). 


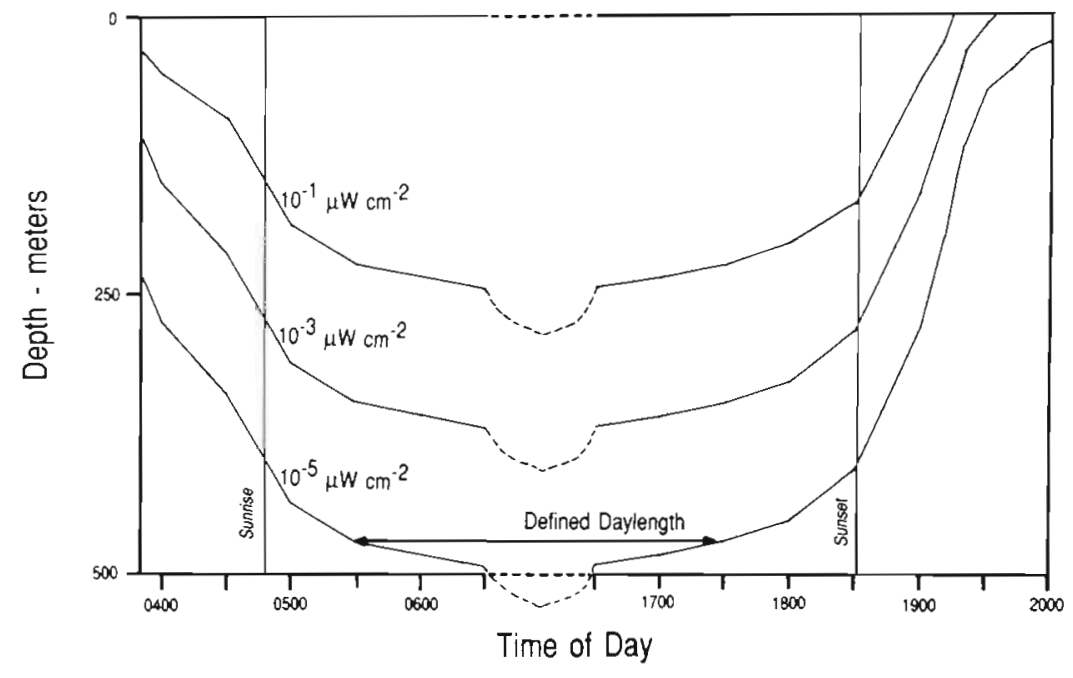

b

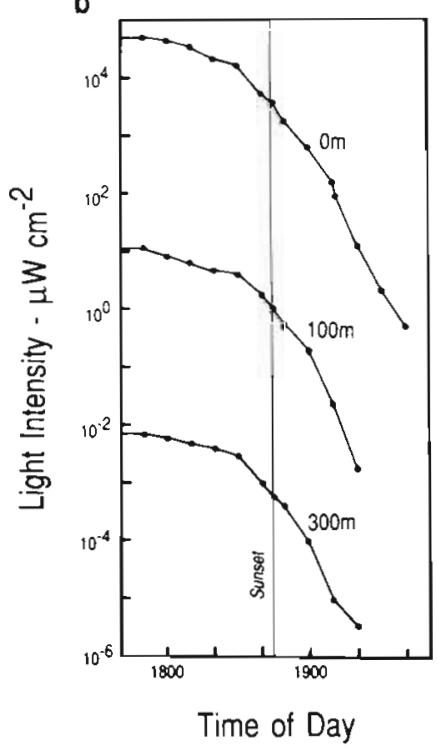

Fig. 6. (a) Position of several isolumes with respect to time of day. An arbitrarily defined daylength is shown. For progressively lower intensities at progressively greater depths, the defined daylength is the same. Curves were calculated from a time series of near-surface, downwelling irradiance and profiles of transmissivity. Redrawn from Clarke \& Backus (1964). (b) Time series of downward irradiance measures obtained at progressively greater depths during the sunset interval. Irradiance changes in the same temporal pattern at all depths, demonstrating that 'defined submarine daylengths' [see (a)] are the same at all depths. Redrawn from Clarke \& Kelly (1965)

(2) In deep water off New England the resting C5 stay very close to $500 \mathrm{~m}$ (Figs. 3 \& 4). (3) Gnathobase (Table 4) and gonad development data (Table 5) show that arousal in the field occurs principally in FebruaryMarch with a tendency for males to precede females. That agrees with previous data, particularly observations of a population in Balsfjorden at $70^{\circ} \mathrm{N}$ (Tande 1982).

If we seek a single hypothesis, the facts suggest that arousal in the field at depth is cued by increasing photoperiod in late winter. We will develop that possibility first, then show an alternate possibility.

Maintenance of narrow layering in depth implies that the resting $\mathrm{C} 5$ stock has an environmental cue to depth, and that they adjust their positions at least intermittently. Light is the obvious cue; it is by no means utterly dark at $500 \mathrm{~m}$. Fig. 6a is redrawn from Clarke \& Backus (1964). It shows August illumination of about $10^{-5} \mu \mathrm{W} \mathrm{cm} \mathrm{cm}^{-2}$ at $500 \mathrm{~m}$, which Clarke (1971) indicates is about the limit inducing phototaxis in Crustacea. Stearns \& Forward (1984) found phototaxis in Acartia tonsa at intensities down to $2.8 \times 10^{11}$ photons $\mathrm{m}^{-2} \mathrm{~s}^{-1}$, which is ca $5.6 \times 10^{-5} \mu \mathrm{W} \mathrm{cm} \mathrm{cm}^{-2}$. The more oceanic Calanus finmarchicus is almost certainly at least this sensitive.

Probably $500 \mathrm{~m}$ is not an accidental level; intensities have been measured at $500 \mathrm{~m}$ as high as $10^{-3} \mu \mathrm{W} \mathrm{cm} \mathrm{cm}^{-2}$ (Clarke \& Kelly 1965), well above the limit of lightsensing capability for small curstaceans. Fig. 6a also shows that deep-sea daylength, defined by progressively lower intensities at greater depths, is roughly constant with depth. Direct measurements by Clarke \& Kelly (1965; Fig. 6b here) accord with the calculations of Clarke \& Backus, demonstrating that isolumes only move sharply close to sunset (and presumably sunrise). Thus, it is expected that daylength (as defined in Fig. 6a) will be a roughly constant fraction of daylength at the surface (Table 6).

Daylength at $500 \mathrm{~m}$ (duration of $>10^{-5} \mu \mathrm{W} \mathrm{cm}^{-2}$ ) will be about 80 to $100 \mathrm{~min}$ less than the sunrise-sunset interval, but it will have the same proportional seasonal change to act as a seasonal cue. In terms of fractional increase per day, change of daylength accelerates markedly in February, and could be an arousal signal

Table 6. Daylength at $40^{\circ} \mathrm{N}$ (Slope Water area) in late winter

\begin{tabular}{|ccc|}
\hline & $\begin{array}{c}\text { Sunrise-sunset } \\
(\mathrm{h})\end{array}$ & $\begin{array}{c}\text { \% Change } \\
\text { from solstice }\end{array}$ \\
\hline Winter solstice & 9.32 & - \\
1 Jan & 9.40 & 0.9 \\
$15 \mathrm{Jan}$ & 9.63 & 3.3 \\
1 Feb & 10.17 & 9.1 \\
15 Feb & 10.75 & 15.3 \\
1 Mar & 11.27 & 20.9 \\
15 Mar & 11.92 & 27.9 \\
Spring equinox & 12.18 & 30.7 \\
\hline
\end{tabular}


for dormant C5's of Calanus finmarchicus. This scheme also could explain the Grigg \& Bardwell (1982) result; if the resting C5's are moved to the surface, they are suddenly subject to longer daylengths and termination is initiated. In fact, even night illuminance close to the surface usually exceeds $10^{-5} \mu \mathrm{W} \mathrm{cm} \mathrm{cm}^{-2}$, so photoperiod automatically would increase in the field. This would have survival value. If a C5 is moved by water circulation into surface layers at a time other than the usual maturation season, its best strategy may well be to return to the active phase, to mature, and to reproduce.

This scheme, like the others to follow, must be able to produce the observed similarity of arousal times over the entire range from our site at roughly $40^{\circ} \mathrm{N}$ to at least $70^{\circ} \mathrm{N}$, the latitude of Balsfjorden (Tande 1982), where the sun is below the horizon from 20 November to 20 January. We are uncertain about this. The arousal in Balsfjorden must be rapid after 20 January to give the timing shown by Tande (1982), which is not different from that we observed at $40^{\circ} \mathrm{N}$. The apparent change in daylength will be much greater farther to the north, and the early post-dark rate of change greater, simply because the total change from continuous dark to the equinox is $12 \mathrm{~h}$ instead of the 2.9 at $40^{\circ} \mathrm{N}$. This is surely an adequate signal, but it seems likely to be available only very close to actual maturation, compared to lower latitudes. Again, phenological features are the traits most amenable to evolution for regional or latitudinal adaptation. Tande et al. (1985) consider a population found even farther north, in the Arctic sector of the Barents Sea, as likely to be expatriates in waters unsuitably cold for sustaining the full life cycle.

Another, more complex, possible scheme is that the arousal mechanism has 2 parts. First, any marked increase in illumination (either intensity or duration) would trigger arousal. The survival value of this would be as explained above. Second, an endogenous, longrange timer could trigger arousal and maturation at depth. This would explain the rough synchrony of arousal in the field. An endogenous, interval timer is more strongly suggested by data for other Calanidae, which we review below. A problem with the notion of an endogenous timer is that actual demonstrations of long-range timers are few in zoology as a whole, and none seem very reliable. A timer that measures a large fraction of a year was claimed by Blake (1958) for Anthrenus verbasci (L.), a beetle whose larvae develop in birds' nests. However, the diapause duration of $A$. verbasci is affected by photoperiod in several ways (Blake 1960, 1963), and Tauber et al. (1986) report that Blake's observations have not been duplicated when an attempt was made. Similar claims of long-term activity cycles (which recur with modified period when free-running under constant conditions) have been made for various mites (reviewed by Saunders 1982), but again Tauber et al. (1986) recommend cautious interpretation ('further study').

A final possibility is that there is no termination cue and no particularly sophisticated timer. According to Tauber et al. (1986): 'for most temperate-zone species [of insects] that undergo an overwintering diapause and in which the conditions influencing diapause maintenance have been examined throughout the winter and spring, no specific diapause-terminating stimulus has been identified. Rather, sometime during winter, the insects cease to respond to diapause-maintaining factors, and diapause ends gradually and spontaneously sometime during late fall or early winter' [italics ours].

That is not to say no well-studied animals have specific cues for diapause termination - many do. However, some factor related to the season and detectable at $500 \mathrm{~m}$, such as shortening (or simply short) photoperiods could maintain the rest phase in Calanus finmarchicus. It would end a variable, probably temperature-dependent, interval after the winter solstice.

Experimental examination of these possibilities should be straightforward, although not easily achieved given the inaccessible habitat of the resting phase and the difficulties of both long term maintenance and continuous rearing for Calanus finmarchicus (Marcus \& Alatalo 1989). Miller \& Grigg (in press) report an initial examination of photoperiod effects, but more experimentation is required.

\section{Arousal mechanisms in other Calanidae}

The range of circumstances surrounding arousal in other Calanidae suggests that either a long-range timer or a direct response to strong illumination is probably the dominant arousal mechanism in other species. For example, Neocalanus plumchrus matures and spawns at depth without ascending to the surface or needing to feed. In coastal habitats where it has been studied (Fulton 1973, Georgia Strait; Miller \& Terazaki 1989, Sea of Japan), it matures mostly in January and early February. In the more oceanic Gulf of Alaska, it matures over a wide range of dates from August through January (Miller \& Clemons 1989). The resting C5's live at depths between 400 and $2000 \mathrm{~m}$ in the oceanic part of the range. At the deeper levels they would receive no cues from seasonal light variation. There is probably an interval timer of some sort. The difference in its setting between coastal and oceanic habitats may depend upon the nutrition available during growth. That would be decidedly less in the open sea (Dagg \& Walser 1987).

Neocalanus flemingeri rests in the Gulf of Alaska as mated females with small, inactive ovaries. It under- 
goes ovarian ripening in December and spawns during January (Miller \& Clemons 1989). This, too, could depend upon an interval timer by the same argument as for $N$. plumchrus. There is not likely to be enough light to provide seasonal cues at all of the depths inhabited, and the depth range for the resting phase ( 400 to $2000 \mathrm{~m}$ ) is so great that light could not provide a consistent cue throughout. Other seasonal cues operating in mid-winter at these depths are hard to imagine. Every physical variable is either extremely constant or varies with a nonseasonal period.

Conover $(1965,1988)$ showed that C5's of Calanus hyperboreus from the arctic (and western subarctic Atlantic) would molt to $\mathrm{C} 6$ in the laboratory during the fall-winter season regardless of the season of collection. It is hard to see how they could receive much daylength information under sea ice at great depths. Conover simply held some C5's in coolers until they matured. He specifically invokes an interval timer in describing his results: 'Apparently C5 C. hyperboreus can remember the correct month in which to molt for up to 305 days of laboratory captivity.... Fulton (1973) cited a similar result from experiments with Neocalanus plumchrus.

In contrast, we suspect that the tropical species Calanoides carinatus has a purely light-stimulated arousal mechanism. It has somewhat different arousal times on the Atlantic and Indian sides of Africa, and perhaps to the north and south of the equator. In the Gulf of Guinea along the Ivory Coast (Binet \& Suisse de Sainte Claire 1975, Binet 1979, Mensah 1974a, b) there is a period of upwelling from June through September (much the strongest in July) which brings the resting C5's to the surface in the region of the shelf (Liberia, Ivory Coast, Ghana). They mature and spawn, and the offspring carry through 4 to 6 full life cycles with 9 to 23 d development time (typically $16 \mathrm{~d}$ ). The final generation of September-October returns as C5's to deep water offshore of the continental slope. Sea surface temperatures during this 'cool' season activity are around $20^{\circ} \mathrm{C}$, contrasting with warm season temperatures around $26^{\circ} \mathrm{C}$.

Off east Africa the Calanoides carinatus growing season presumably corresponds to the period of the southwest monsoon which is from late April-early May until October (Smith 1982, 1984). There has never been a study comparable to Binet's to show how close the correspondence is to the whole period of monsoonal upwelling, since there has not been late season sampling. There are only small seasonal variations in daylength and irradiance throughout the range, so that photoperiod arousal cues probably could not be received at depth. An a priori guess is that light is a direct stimulus; when the C5's are moved near the surface layer by feeder flows to the upwelling, they mature, initiate feeding, and spawn. Warming is another potential cue, since the rising layers are heated by mixing and insolation. The mechanism should be amenable to a direct experimental evaluation, provided that $C 5$ 's can be collected alive and relatively uninjured from depth.

\section{Correlation of arousal mechanisms and habitat}

This contrast between the likely arousal mechanisms in the Calanidae of different regions has a clear correlation to the relationships of the animals to their habitats. In mid- and high latitude systems the animals need to anticipate the season of maximum production, which is predictable in time. Moreover, production variations are roughly contemporary over large parts of the range, certainly throughout the region underlain by deep water containing resting populations. So, they rise (literally) for work on the schedule proved successful by their ancestors. They either do this by responding to an internal 'alarm clock', or by responding to seasonally appropriate daylengths. In the tropical regions where upwelling sites are the only suitable near-surface habitats, the upwelling schedule varies from site to site. Moreover, upwelling conditions (cool, high productivity) are not established directly above the deep water containing the resting populations. The best strategy would be to stay in the resting phase until the feeder flow carries them to an upwelling site, then complete development in response to increased light or temperature.

Calanus finmarchicus, $C$. helgolandicus and their relatives appear to retain mechanisms allowing for both contingencies. If moved to the surface at a seasonally inopportune time, the best strategy is to wake up, to resume responding to things like fish attacks, and to prepare for feeding and reproduction. However, the best time for arousal remains early winter, and individuals still resting will contribute most to future generations by reactivation at that time, a time indicated by photoperiod or by an internal timer.

Acknowledgements. Support of sampling and analysis by NSF grants 80-19055 and 81-17271 to Woods Hole Oceanographic Institution is gratefully acknowledged Manuscript preparation was supported by NSF grant OCE-8911520 to Oregon State University. Very useful reviews were received from Bruce Frost, Mark Huntley, and several anonymous reviewers. We thank them for their help.

\section{LITERATURE CITED}

Alldredge, A. L., Robison, B. H., Fleminger, A., Torres, J. J., King, J. M., Hamner, W M. (1984). Direct sampling and in situ observation of a persistent copepod aggregation in the mesopelagic zone of the Santa Barbara Basin. Mar. Biol. 80: $75-81$ 
Bigelow, H. B. (1926). Plankton of the offshore waters of the Gulf of Maine. Bull U.S. Bur. Fish. 40, 1924, Part II: 1-507

Binet, D. (1979). Le zooplancton du plateau continental ivoirien. Essai de synthese ecologique. Oceanologica Acta 2: $397-410$

Binet, D., Suisse de Sainte Claire, E. (1975). Le copepode planctonique Calanoides carinatus, repartition et cycle biologique au large de la Côte D'Ivoire. Cah. O.R.S.T.O.M. Ser. Océanogr. 13: 15-30

Blake, G. M. (1958). Diapause and the regulation of development in Anthrenus verbasci (L.) (Col., Dermestidae). Bull ent. Res. 49: 751-775

Blake, G. M. (1960). Decreasing photoperiod inhibiting metamorphosis in an insect. Nature, Lond. 188: 168-169

Blake, G. M. (1963). Shortening of a diapause-controlled lifecycle by means of increasing photoperiod. Nature, Lond. 198: $462-463$

Butler, E. J., Corner, E. D. S., Marshall, S. M. (1970). On the nutrition and metabolism of zooplankton. VII. Seasonal survey of nitrogen and phosphorus excretion by Calanus in the Clyde-Sea area. J. mar. biol. Ass. U.K. 50: 525-560

Caswell, H. (1982). Optimal life histories and the maximization of reproductive value: A general theorem for complex life cycles. Ecology 63: 1218-1222

Clarke, G. L. (1971). Light conditions in the sea in relation to the diurnal vertical migrations of animals. [n: Farquhar, G. (ed.) Proc. Intern. Symp. on Biological Sound Scattering in the Sea. Maury Center for Ocean Sci; Dept. Navy, Washington, D.C., p. 41-50

Clarke, G. L., Backus, R. H. (1964). Interrelations between the vertical migration of deep scattering layers, bioluminescence, and changes in daylight in the sea. Bull. Inst. océanogr., Monaco 64: 1-36

Clarke, G. L., Kelly, M. G. (1965). Measurements of diurnal changes in bioluminescence from the sea surface to 2,000 $\mathrm{m}$ using a new photometric device. Limnol. Oceanogr. 10: R54-R66

Conover, R. J. (1965). Notes on the molting cycle, development of sexual characteristics and sex ratio in Calanus hyperboreus. Crustaceana 8: 308-320

Conover, R. J. (1988). Comparative life histories in the genera Calanus and Neocalanus in high latitudes of the northern hemisphere. Hydrobiologia 167/168: 127-142

Corner, E. D. S., Head, R. N., Kilvington, C. C., Marshall, S. M. (1974). On the nutrition and metabolism of zooplankton. IX. Studies relating to the nutrition of overwintering Calanus. J. mar biol. Ass. U.K. 54: 319-331

Dagg, M. J., Walser, W. E. (1987). Ingestion, gut passage, and egestion by the copepod Neocalanus plumchrus in the laboratory and in the subarctic Pacific Ocean. Limnol. Oceanogr. 32: 178-188

Elgmork, K., Nilssen, J. P. (1978). Equivalence of copepod and insect diapause Verh. int theor angew. Limnol. 20: $2511-2517$

Fish, C. J. (1936). The biology of Calanus finmarchicus in the Gulf of Maine and Bay of Fundy. Biol. Bull mar. biol. Lab., Woods Hole 70: 118-141

Fisher, R. A. (1930). The genetical theory of natural selection. Clarendon Press, Oxford

Fulton, J. (1973). Some aspects of the life history of Calanus plumchrus in the Strait of Georgia. J. Fish. Res. Bd Can. 30: $811-815$

Grigg, H., Bardwell, S. J. (1982). Seasonal observations on moulting and maturation in Stage $\mathrm{V}$ copepodites of Calanus finmarchicus from the Firth of Clyde. J. Mar. biol. Ass. U.K. 62: 315-327

Grigg, H., Bardwell, S. J., Holmes, L. J. (1987). Comparative observations on the biometry and development of Calanus finmarchicus and $C$. helgolandicus in copepodite stage $V$, with comments on other Calanidae. Mar. Biol. 96: 253-262

Grigg, H., Bardwell, S. J., Tyzack, S. (1981). Patterns of variation in the prosome length of overwintering stage $V$ copepodites of Calanus finmarchicus in the Firth of Clyde. J. mar. biol. Ass. U.K. 61: 885-899

Grigg, H., Holmes, L. J., Bardwell, S. J. (1985). Seasonal observations on the biometry and development in copepodite stage $\mathrm{V}$ of Calanus finmarchicus from the Firth of Clyde. Mar. Biol. 88: 73-83

Grigg, H., Holmes, L. J., Bardwell, S. J. (1989). Patterns of variation in the dry body weight of Calanus finmarchicus in copepodite stage $\mathrm{V}$ during autumn and winter in the Firth of Clyde. J. mar. biol. Ass. U.K. 69: 101-122

Hairston, N. G. Jr. (1987). Diapause as a predator-avoidance adaptation. In: Kerfoot, W. C., Sih, A. (eds.) Predation, direct and indirect impacts on aquatic communities. Univ. Press of New England, Hanover, p. 281-290

Hairston, N. G., Jr., Olds, E. J. (1987). Population differences in the timing of diapause: a test of hypotheses. Oecologia (Berl.) 71: 339-344

Hallberg, E., Hirche, H.-J. (1980). Differentiation of mid-gut in adults and over-wintering copepodids of Calanus finmarchicus (Gunnerus) and C. helgolandicus Claus. J. exp. mar. Biol. Ecol. 48: 283-295

Herman, A. W., Sameoto, D. D., Shunnien, C., Mitchell, M. R., Petrie, B., Cochrane, N. (in press). Sources of zooplankton on the Nova Scotia shelf and their aggregations within deep shelf basins. Cont. Shelf Res.

Hirche, H.-J. (1983). Overwintering of Calanus finmarchicus and Calanus helgolandicus. Mar Ecol. Prog. Ser. 11: 281-290

Hirche, H.-J. (1989). Spatial distribution of digestive enzyme activities of Calanus finmarchicus and C. hyperboreus in Fram Strain/Greenland Sea. J. Plankton Res. 11: 431-443

Hochochka, P., Somero, G. (1984). Biochemical adaptation Princeton Univ. Press, Princeton

Johnson, J. K. (1979). Effects of temperature and salinity on production and hatching of dormant eggs of Acartia californiensis (Copepoda) in an Oregon estuary. Fish. Bull. U.S. 77: 567-584

Marcus, N. (1982). Photoperiodic and temperature regulation of diapause in Labidocera aestiva (Copepoda: Calanoida). Biol. Bull. mar biol. Lab., Woods Hole 162: 45-52

Marcus, N. (1984). Variation in the diapause response of Labidocera aestiva (Copepoda: Calanoida) from different latitudes and its importance in the evolutionary process Biol. Bull mar. biol. Lab., Woods Hole 166: 127-139

Marcus, N. H., Alatalo, P. (1989). Conditions for rearing Calanus finmarchicus (Gunnerus, 1770) (Copepoda, Calanoida) through multiple generations in the laboratory. Crustaceana 57: 101-103

Marshall, S. M. Nicholls, A. G., Orr, A. P. (1934). On the biology of Calanus finmarchicus. V Seasonal distribution, size, weight and chemical composition in Loch Striven in 1933 and their relation to the phytoplankton. J. mar. Biol. Ass. U.K. 19: 793-828

Marshall, S. M., Orr, A. P. (1958). On the biology of Calanus finmarchicus. $X$. Seasonal changes in oxygen consumption. J. mar Biol. Ass. U.K. 37: 459-472

Mensah, M. A. (1974a). The occurrence of the marine copepod Calanoides carinatus (Kroyer) in Ghanaian waters Ghana J. Sci. 14: 147-166

Mensah, M. A. (1974b). The reproduction and feeding of the marine copepod Calanoides carinatus (Kroyer) in Ghanaian waters. Ghana J. Sci. 14: 167-191 
Miller, C. B., Clemons, M. J. (1988). Revised life history analysis for large grazing copepods in the subarctic Pacific Ocean. Prog. Oceanogr 20: 293-313

Miller, C. B., Grigg, H. (in press). An experimental study of the resting phase in Calanus finmarchicus (Gunnerus). Proc. 4th Int. Conf. Copepoda. Bull. Plankton Soc. Japan

Miller, C. B., Nielsen, R. D. (1988). Development and growth of large, calanid copepods in the ocean[ic] subarctic Pacific. Prog. Oceanogr 20:275-292

Miller, C. B., Terazaki, M. (1989). The life histories of Neocalanus flemingeri and Neocalanus plumchrus in the Sea of Japan. Bull. Plankton Soc. Japan 36: 27-41

Nilssen, J. P. (1980). When and how to reproduce: a dilemma for limnetic cyclopoid copepods. In: Kerfoot, W. (ed.) Evolution and ecology of zooplankton communities. Univ. Press of New England, Hanover, p. 418-426

Saunders, D. S. (1982). Insect clocks. Pergamon Press, Oxford

Sherman, K. (1980). MARMAP, a fisheries ecosystem study in the Northwest Atlantic: Fluctuations in icthyoplanktonzooplankton components and their potential for impact on the system. In: Diemer, F. P., Vernberg, F. J., Mirkes, D. Z. (eds.) Advanced concepts in ocean measurements for marine biology. Belle W. Baruch Libr. Mar. Sci., No. 10 , Univ. S. Carolina Press, Columbia, p. 9-37

Smith, S. L. (1982). The northwestern Indian Ocean during the monsoons of 1979: distribution, abundance, and feeding of zooplankton. Deep Sea Res. 29A: 1331-1353

Smith, S. L. (1984). Biological indications of active upwelling in the northwestern Indian Ocean in 1964 and 1979, and a comparison with Peru and Northwest Africa. Deep Sea Res. 31A: 951-967

Stearns, D. E., Forward, R. B., Jr (1984). Photosensitivity of the calanoid copepod Acartia tonsa. Mar. Biol. 82: 85-89

Sullivan, B. K., McManus, L. T (1986). Factors controlling seasonal succession of the copepods Acartia hudsonica and $A$. tonsa in Narragansett Bay, Rhode Island: temperature and resting egg production. Mar. Ecol. Prog. Ser 28: $121-128$

Tande, K. S. (1982). Ecological investigations on the zooplankton community of Balsfjorden, Northern Norway: generation cycles, and variations in body weight and body content of carbon and nitrogen related to overwintering and reproduction in the copepod Calanus finmarchicus (Gunnerus). J. exp. mar Biol. Ecol. 62: 129-142

Tande, K. S., Hassel, A., Slagstad, D. (1985). Gonad maturation and possible life cycle strategies in Calanus finmarchicus

This article was presented by Drs B. and E. Shert, Corvallis, Oregon, USA and Calanus glacialis in the northwestern part of the Barents Sea. In: Gray, J. S., Christiansen, M. E. (eds.) Marine biology of polar regions and effects of stress on marine organisms. John Wiley \& Sons, New York, p. 141-155

Tande, K. S., Hopkins, C. C. E. (1981). Ecological investigations of the zooplankton community of Balsfjorden, northern Norway the genital system in Calanus finmarchicus and the role of gonad development in overwintering strategy. Mar Biol. 63: 159-164

Tande, K. S., Slagstad, D. (1982). Ecological investigations of the zooplankton community of Balsfjorden, northern Norway: seasonal and short-time variations in enzyme activity in copepodite stage $V$ and stage VI males and females of Calanus finmarchicus (Gunnerus). Sarsia 67: 63-68

Tauber, M. J., Tauber, C. A., Masaki, S. (1986). Seasonal adaptation of insects. Oxford Univ. Press, New York

Uye, S. (1986). Resting egg production as a life history strategy of marine planktonic copepods. Bull. mar. Sci. 28: 121-128

Uye, S., Fleminger, A. (1976). Effect of various environmental factors on egg development of several species of Acartia in Southern California. Mar. Biol. 38: 253-262

Watson, N. H. F., Smallman, B. N. (1971a). The role of photoperiod and temperature in the induction and termination of an arrested development in two species of freshwater cyclopoid copepods. Can. J. Zool. 49: 855-862

Watson, N. H. F., Smallman, B. N. (1971b). The physiology of diapause in Diacyclops navus Herrick (Crustacea, Copepoda). Can. J. Zool. 49: 1449-1454

Wiebe, P. H., Morton, A. W., Bradley, A. M., Backus, R. H., Craddock, J. E., Barber, V., Cowles, T. J., Flierl, G. R. (1985). New developments in the MOCNESS, an apparatus for sampling zooplankton and micronekton. Mar. Biol. 87: 313-323

Williams, R. (1985). Vertical distribution of Calanus finmarchicus and $C$. helgolandicus in relation to development of the seasonal thermocline in the Celtic Sea. Mar. Biol. 86: $145-149$

Williams, R. (1988). Spatial heterogeneity and niche differentiation in oceanic zooplankton. In: Boxshall, G. A., Schminke, H. K. (eds.) Biology of copepods. Hydrobiologia 167/168: 151-159

Williams, R., Conway, D. W. P. (1988). Vertical distribution and seasonal numerical abundance of Calanidae in oceanic waters to the south-west of the British Isles. In: Boxshall, G. A., Schminke, H. K. (eds.) Biology of copepods. Hydrobiologia 167/168: 259-266

Manuscript first received: October 25, 1990

Revised version accepted: February 28, 1991 